\title{
POLISH STRATEGIC ANALYSES - REVIEW OF 2017 PUBLICATIONS
}

In 2015 the "Strategic Review" has started a regular column presenting and commenting on recent papers from the field of International Security Studies published in leading Polish academic journals dealing with International Relations and Security Studies. The texts from the last three years reviewed in subsequent articles offered a reflection on the evolving international security environment of our times, as well as academics' attempts to describe and explain it. And turbulent times these were. The first instalment of our review covered 2014, the year in which war engulfed Ukraine and IS proclaimed its caliphate. Looking from the perspective of early 2018 we can discern at least the emergence of clearer contours defining something approaching the "new normal" of what (from a lack of a better term) can be dubbed the "postpost-Cold War" order. Although such conclusions are preliminary and may turn out to be premature, it can be claimed that an important turn is underway concerning key international security issues. This change is visible both in policymaking circles and among researchers. It can be summarised as: "the state, war and power politics are back." Obviously, looking at the history of ISS it is clear that its very origins lie in the study of the nation state as a reference object of security and its defence policy vis-àvis other states. With time, the field of research has been (rightly) widened to encompass a wide spectrum of non-military issues as pertaining to both state and non-state actors. It can be claimed that especially in the post-Cold War period the attention of both security policy-makers around the world and ISS researchers has shifted towards a range of issues often described as "new" or "non-traditional" security issues, like terrorism, transnational crime, migration, environment, economic and social problems etc. Naturally, the traditional ISS topics of interstate warfare, deterrence and balance of power never really disappeared. However, it can be claimed that the "cutting edge" of our discipline has moved to somewhat different territory. Looking from the perspective of time passed it seems only natural that events took such a direction. Such was the international security environment of the first two post-Cold War decades.

At some point in the XXIst century's second decade this situation changed. It is very difficult to pinpoint the exact turning point. Perhaps it was the global financial crisis starting in 2008 which led to pervasive doubts about the character of globalisation and reaffirmed the role of the nation state as guarantor of economic stability. It clearly coincided with gradual shift in the global balance of power towards so-called "emerging powers" of non-Western world. However we choose to view it, around 2014 it became clear that the world has entered another period of heightened great power rivalry. 
This is reflected in countless academic, analytical and official publications. However, maybe one of the starkest examples is the new National Security Strategy of United States published in December 2017. Analysis and recommendations of this documents are clearly based " $[\ldots]$ upon the view that peace, security, and prosperity depend on strong, sovereign nations that respect their citizens at home and cooperate to advance peace abroad" (National Security Strategy, 2017: 1). Moreover, strategy's authors are very clear in their assessment that: "China and Russia challenge American power, influence, and interests, attempting to erode American security and prosperity" (National Security Strategy, 2017: 2). It has also been reflected in the Concept of Defence of Republic of Poland published in 2017. Analysing main trends shaping Poland's security environment the document states that: "The status quo based on international law has undergone a series of shocks. This has been the result mainly of individual countries to play more important roles in the regional or global orders. [original spelling from the document - RW] Although their motives differ, they usually voice postulates to restrict the domination of the United States. These narratives arguing for a revision of the international order often go along with ambitions for territorial expansion" (Concept of Defence, 2017: 18). In this context it is only natural that International Security Studies responded to these developments through a renewed focus on their traditional topics of balance of power, state security policy, war and deterrence. This shift is visible in papers reviewed in this article. They present a (necessarily) subjective selection made by this author from texts published in the course of 2017 in five Polish periodicals dealing with ISS issues - "Kwartalnik Bellona" ("Bellona Quarterly"), "Polish Quarterly of International Affairs," "Rocznik Strategiczny" ("Strategic Yearbook"), "Sprawy Międzynarodowe" ("International Affairs") and "Stosunki Międzynarodowe" ("International Relations").

The current mood in Polish strategic studies community has been reflected in the first meeting of a Consortium of Strategic Studies Departments, held in Warsaw in April 2017. This initiative is centred on regular meetings of scholars and analysts from leading Polish institutions working on international security issues, organised by strategic studies departments from three leading Universities (Adam Mickiewicz University, Jagiellonian University and University of Warsaw). The topic of this very first meeting concerned the perspectives for a new "great war." Main reflections from this seminar are summarised in an article by Miron Łakomy entitled Intensyfikacja rywalizacji mocarstw jako zagrożenie militarne dla bezpieczeństwa międzynarodowego $w$ drugiej dekadzie XXI wieku [Intensification of great power rivalry as a military threat for international security in the second decade of the XXIst Century], published in "Stosunki Międzynarodowe" (Łakomy, 2017). The author of that article aims to answer two research questions highly relevant for the current international order: 1) is the probability of a "great war" increasing ("great war" is defined by him as a one in which great powers are engaged on both sides) 2) what forms will great power rivalry take in the future. Arguably, these are the questions strategic studies were created to answer. The fact that discussion during the Strategic Studies Consortium's inaugural seminar revolved around them is another example of the discipline "going back to its roots" as described earlier. Łakomy clearly states that recently the world has entered a period of heightened great power rivalry. The explanation for this change lies in the 
changing global balance of power as well as a series of disputes and conflicts involving major powers. The global power shift, away from the dominant position of USA and the West in general towards growing strength of the so-called "emerging powers" is a well-known and researched phenomenon. A series of conflicts in which great powers clashed enumerated by Łakomy (which includes Kosovo, Georgia, Libya, Ukraine and Syria) amounts to a chronicle of growing disagreement between these two groups of states concerning the shape and meaning of the international order.

When answering his first question, concerning the prospects for a "great war," the author cites a growing number of incidents and military crisis involving great powers - especially USA, Russia and China. Many analysis of the current international security situation explain it in terms of a challenge presented by Beijing and Moscow towards the US-led international order. Looking at this problem from a broader perspective, one cannot fail to observe that the visions of international order promoted by United States on one side and Russia/China on the other are starkly at odds with one another. Having said that, in my opinion, a claim that Beijing and Moscow's aims amount to overthrow and full-scale change of the current international order is premature. Rather, it can be argued that both major powers aim to renegotiate their respective positions in the current international order and ensure the protection of their vital interests (like regime security). Such reflections provide a useful background and commentary to Łakomy's analysis which includes also some more tangible metrics to asses great powers' propensity for war. He cites four such indicators: the level of defence expenditure, number and scale of military exercises, frequency of armed incidents and scale of military deployments outside one state's borders. In the last several years all these indicators pointed towards growing belligerence among major international players. This facts are beyond dispute. However, without questioning the utility of following such easily observable material indicators, the actual probability of a great war is more dependent on states' intentions. Military expenditure, troop exercises or overseas force projection can serve many purposes beyond preparations for commencement of actual hostilities. They can easily be interpreted as serving as signalling tolls or elements of deterrence strategies. We cannot properly answer the questions about the likelihood of another major war without delving deeper into major players' motives, strategies and worldviews. When viewing the current situation through these lenses the prospects for another cataclysmic conflict seem less alarming as none of the great powers seems to deliberately uses unrestrained military force to further its national interests. That is also recognised by Łakomy who concludes that another great war is not particularly likely to happen soon because of perseverance of Mutually Assured Destruction which raises the costs of potential conflict above the reasonably acceptable level. At the same time, it is worth remembering that wars are not always initiated based on rational calculation. They can as well arise from miscalculation, especially in a situation in which leaders develop an "insensitivity to crises" (Ja Ian Ching, Hall, 2014: 33-36).

Diagnosis presented in the previous paragraph leaves us with the second question posted by Łakomy. If great powers will not engage in a large scale war due to its prohibitive cost, then what forms will they choose for their rivalry? Answering this the author of the discussed article predicts a growing use of actions and instruments below 
the threshold of open warfare. They include the (oft discussed) hybrid warfare, cyber operations, disinformation or even weaponization of migration. Current trends and events in the international security environment prove that Łakomy's conclusions are correct. With global balance of power still tilted in USA's favour challengers increasingly employ creative combinations of various tools to further their aims in numerous international disputes and conflicts. Russian actions undertaken against Ukraine and (to a lesser extent) NATO countries or Chinese assertive posture in the South China Sea are only the most prominent examples of what can be described as "hybrid strategies" (Wiśniewski, 2018 upcoming). When trying to explain the character of contemporary international conflicts scholars and analysts often employ such concepts as "grey zone conflicts" (Mazarr, 2015) or "Unrestricted Warfare" (Qiao Liang, Wang Xiangsui, 1999). Thus when answering a question about the likelihood of a major war it is tempting to answer: The war is already under way, it is just waged in a very different way to which we are accustomed. One more interesting aspect of Łakomy's text deserves a mention and comment. He clearly defines wars in Ukraine and Syria as "proxy wars" between Russia and the West. It is quite understandable to view these conflicts in such a way, as Russia and the West clearly support opposing sides in them. However, in my opinion the picture is more complicated. By definition a proxy war is a conflict in which great powers engage for the primary purpose of countering each other's moves. Ukrainian conflict can fit this description on a political level. Russia invaded Ukraine to stop it from joining the "Western block," while Western countries sanctioned Moscow and supported the Kyiv government in order to check Russian expansionism. However, at the military level Russia has shown a far greater readiness to support its proxies with arms. The West has shied away from meaningful military support to Ukraine. The divergence from "proxy war" model is even more evident in the Syrian case. The primary aim of American involvement in this conflict since 2014 has been to defeat Islamic State, not to topple the Assad regime or dislodge Russian influence. From the Russian perspective "the American factor" seemed to be more important when the decision about a direct military intervention had been made. In any instance, recurring offers of US-Russia cooperation or at least "deconfliction" of operations in Syria hardly fit the proxy war framework. Naturally, a caveat is in order, that situation in both conflict zones is evolving very rapidly and by the time this analysis is being read the reality may be starkly different.

While Miron Łakomy's article analyses the intensification of great power rivalry and prospects for its evolution into open warfare, two other texts provide background which can be viewed as prologue and epilogue to this topic. It has already been mentioned that global power shift is an important factor conditioning the current resurgence of great power rivalry. An article by Mirosław Sułek entitled Transformacja globalnego uktadu sit po zimnej wojnie [Transformation of the global balance of power after the Cold War], published in "Rocznik Strategiczny," explains how that change occurred and what are the prospects for its future evolution. (Sułek, 2017) Thus, the power realignment descried by Sułek provides a nice prologue to Łakomy's analysis. In the same manner a text by Bolesław Balcerowicz - O przyszłych wojnach [On future wars] in "Bellona" gives more of a sense of how this notional great war of the future could actually look like (Balcerowicz, 2017). 
Mirosław Sułek is a well know practitioner of the art of "powermetrics" (pl. potegometria understood as the art and science of measuring national power). He has proposed his own formula to calculate both general power (synonymous with economic power) and military power of a given state. The article under consideration presents results of this equation's application to trace the changes in relative position of major states in the international hierarchy of power for years 1992-2015. Sułek's equation is elegant and clear but at the same time quite simple. The general power is calculated by taking into consideration such factors as GDP, population and territory. The military power is determined by operating on numbers depicting military expenditure and troop numbers. Such an approach obviously has both strengths and weaknesses. Thinking about the history of "powermetry" we can discern two schools of approaching the challenging task of judging national power. One I would call the "school of measurement," the other "school of assessment." The first of these can be traced to the classical Cline formula (Cline, 1975; quoted in Kondrakiewicz, 1999: 54-56) and clearly includes Sułek's approach. It is based on a quantitative analysis of material factors and aims to produce an objective, easily comparable numerical value of state power. Such an approach brings clear benefits of objectivity and clarity. The second school leans towards more qualitative assessment of different factors influencing the scale and usefulness of given state's power. It can be traced to Morgenthau and Thompson's model (Morgenthau, Thompson, 1985, quoted in Kondrakiewicz, 1999: 54-56). Such an assessment is inevitably more subjective, but at the same time reflects the complex reality of states as societies composed of human beings and not a simple machinery mechanically transforming inputs (population, territory, resources) into outputs (a force to influence other actors). This approach takes into account the immaterial factors such as the contents and quality of national strategy, competence of decision makers or public attitudes towards foreign policy. It can be claimed that best results are achieved by a combination of both approaches. For a disclosure I have attempted such a feat together with my co-author in Wisniewski, Hensarling 2015.

Sułek's approach to powermetry is unabashedly quantitative and rooted in realist paradigm. He clearly states his aim as capturing and explaining an important shift in global power distribution in the post-Cold War period. It is accompanied by an observation that: "The struggle for power is a zero (constant)-sum game, which means that the rise in one state's power can only be achieved at the expense of other. This constant sum is the world power, which always amounts to a certain whole (equalling for example $100 \%$ or $1000 \%$ ). States strive for as big a share in it as possible. Considering that the basis is constant comparisons across long historical periods are possible" (Sułek, 2017, 317). Such theoretical and methodological clarity benefits the paper by making the author's argument precise and complete. At the same time, every study based solely on one theoretical approach is left open to challenges based on exclusion of causal mechanisms best described by other theories.

In any case, conclusions drawn from Sułek's analysis of global balance of power are commensurate with well recognized and analysed patterns in global power politics. The author highlights the general decline of the West and high gains for the so-called "emerging," primarily non-Western, powers. Naturally, the biggest beneficiary of this realignment is China. Sułek goes as far as proclaiming the world bi-polar again (based 
on economic metrics, in military terms it is still clearly unipolar). Conventional as these conclusions may look, it is useful to support the whole debate about "global power shift" with some solid quantitative basis. What is perhaps among the most interesting reflections included in the article concerns the effects of globalisation. Sułek enters the raging debate about winners and losers of this process with a clear stance: "Voluntary cooperation leads to mutual benefits, but the scale of the benefits is not equal - it is the weaker, less developed who benefit more than stronger and higher developed. In the longer perspective a tendency towards equalisation of development levels occurs and that provokes nervous reactions in some Western countries. To put it another way, globalisation is especially beneficial for weak and developing states, often to the detriment of incomes and comfort of rich countries' workers. And that is the most common, though often overlooked, cause of protests" (Sułek, 2017: 316). It is a very interesting perspective on discontent gripping most of the West and based on globalisation's effects. Looking at power statistics meticulously compiled by Sułek it is clear that thanks to globalisation such former "Third World" countries like China have make a true "great leap forward." At the same time, there is another argument to be made here. In accordance with the realist approach, Sułek adopts a monolithic nation state as his unit of analysis. However, as pointed out by Sean Starrs, globalization has also changed the characteristics of primary economic actors. China et al. may be growing richer, but main benefits accrue to global elite controlling the Trans-National Corporations. And still USA has the biggest share of top global TNCs (Starrs, 2013).

All these comments notwithstanding Sułek's article provides a very useful and interesting background to wider reflections about great power rivalry (as dealt with in Lakomy's text). Looking at his data, the current period of tensions can be viewed as an attempt by economically declining but militarily still dominant hegemon to withstand a challenge from rapidly rising challenger. The exact form and substance of this struggle is the key to the question of future war and peace in the world.

The possibility of great power rivalry spinning out of control makes predictions about possible forms of future warfare an important element of current strategic studies agenda. In his article published in "Kwartalnik Bellona" Bolesław Balcerowicz reflects on current state of research on the shape and form of military conflicts (Balcerowicz, 2017). The author shortly traces the history of different theories and concepts devised to explain the character of post-cold war conflicts. Catch phrases such as "new" or "virtual" wars proliferated as scholars tried to grasp the essence of subsequent conflicts (taking place in the Balkans and the Middle East). It seems that every Western military intervention provoked a new theory putting its main futures at the centre of the "future wars" model. In his article Balcerowicz does not propose a new theory or model predicting how future wars will be won and lost. He rather presents and criticises the most common concepts which have proliferated during the last two decades. He singles out four such cases: infowar, cyberwar, war in space and hybrid warfare. All of these concepts identify and analyse important aspects of contemporary conflicts - growing role of information as both resource and a weapon, crucial role of cyberspace for societies, reliance on space assets in warfighting and hybrid nature of strategies combining military and non-military means. These realities are recognized by Balcerowicz. His strongest statement concerns the space domain. He claims that: 
"The significance of this fourth dimension [space] has grown to such a degree that it is impossible to disagree with a paraphrase of Halford John Mckinder's rule of geopolitics (and geostrategy): whoever rules space, rules the entire globe" (Balcerowicz, 2017: 17).

Important as all these developments are, the notion that they fundamentally transform the nature of war is treated by Balcerowicz with deep scepticism. He states that: "The nature of war, what Clausewitz includes in his triads, what he describes as a play of chance and probability, remains and in the future will remain unaltered. War is defined by its nature, or putting it differently - by its paradigm. If the war changes its nature, then it becomes something else" (Balcerowicz, 2017: 19). The author strongly articulates his opinion that the very essence of war - physical violence employed for political ends - will not change in the future. He recognises the importance of new spheres of conflict, like cyberspace, but rather as new domains complementing traditional ones (land, sea, air) than supplanting them as a primary arena for warfare. As summarised by the author himself: "Futuristic vision of XXIst Century wars, focused on two dimensions - the fourth (space) and fifth (information) should be considered incomplete. [...] Full spectrum wars - fought on land, sea, in the air, space and cyberspace - will be affordable only for the few" (Balcerowicz, 2017: 18). The conclusions of the article can arguably be boiled down to another quote: "In visions of future wars, it needs to be assumed that large part of them will be similar to the wars of the XXth as well as earlier centuries" (Balcerowicz, 2017: 18). Balcerowicz's article presents a very mature and sober reflection on future war, or rather on our attempts to forecast and conceptualize it. Drawing on history of strategy and its study it aims to strike a balance between clinging to outdated explanations of reality and naively embracing bold predictions about "sea change" in how the world (or war in this particular instance) works.

The entire debate about the return of great power competition can be framed as a return of strategic studies to well-known and understood topics of war and deterrence. However, as the famous adage says: "history does not repeat itself but often rhymes." Current international rivalry is conducted under conditions of an altered international order. Thus, new forms of competition and power politics emerge to complete the classical toolbox of statecraft. An interesting text about one of them has been published by Mariusz Ruszel in "Sprawy Międzynarodowe" under the title Strategia polityki eneregetycznej republiki Federalnej Niemiec [The strategy of energy policy of the Federal Republic of Germany] (Ruszel, 2017). This article nicely contributes to two important debates concerning European security: one concerning Germany's role as a dominant power in the EU and the second about the significance of energy security. Ruszel's main hypothesis is as follows: "coordinated German energy policy based on partnership with the Russian Federation, extensive energy infrastructure and EU climate policy allows for ensuring of energy security and establishment of solid competition advantages on the markets for natural gas, electric power and renewable sources of energy" (Ruszel, 2017: 82-83). Referring to Kundnani's thesis about German geoeconomics the author explains how Berlin is using economic and environmental policies to improve its competitive position in the world economy. Ruszel succinctly analyses how Germany, despite calls for diversification of energy imports' 
sources, is consequently relying on strategic partnership with Moscow to secure stable and affordable gas supplies. Moreover, German gas transfer network is able to service a much larger quantity of the commodity than is required by the needs of German economy. This stems from a fact that Berlin is actively trying to position itself as a hub for reexport of Russian gas to the rest of Europe. Ruszel observes that it creates an interesting paradox for German alliance policy. The more East European NATO members feel threatened by Russia, the more gas they buy from Germany. However, this is still Russian gas. Ruszel poses a question whether Germany would defend its East European allies in an event of a direct military attack from Russia. He answers that Berlin is doing everything it can not to find itself in such a situation. Another interesting topic covered in this article concerns German attempts at international promotion of its energy transformation (Energiewende). Here it is viewed as another mean to build and maintain the competitive advantage of German industry.

Ruszel's article enriches the strategic studies debate in two ways. First it highlights the diversity of strategies employed by major powers to strengthen and maintain their international position. It is about much more than military build-ups or diplomatic grand-standing and also includes many economic, technological or cultural efforts. Second, it provides an interesting reference point for discussion about Germany's role in Europe. Especially in popular, journalistic, discourse two oversimplified positions tend to emerge. One, dwells on an image of Berlin as a malign actor keen to establish hegemonic control over the continent. Although this seems the be rather distant from actual reality, the second image seems to be almost as inaccurate. It tends to describe Germany as a kind of "post-nation state" wholly committed to the ideal of United Europe and exhibiting altruistic motives in tis foreign policy. Ruszel's article shows that Germany, as any other state, is consciously using available tools to strengthen its international position through economic competitiveness.

As already noted, the debate about reinvigorated great power rivalry is focused on two competitive dyads: USA-China and USA-Russia. Inevitably, from the Polish perspective, the latter is more pressing and attracts significantly more academic studies. That is why I wanted to bring into readers' attention three articles which all cover different aspects of Russia-NATO relations and at the same time nicely complement each other. The first two - by Wojciech Lorenz (Lorenz, 2017) and Andrzej Dybczyński (Dybczyński, 2017) - can be viewed as examples of a classical realist take on the issue, as they focus on deterrence and alliance politics. Paulina Matera's text (Matera, 2017) provides an interesting complement to the aforementioned articles by applying constructivist lens for analysis of the antagonism's roots.

Article by Wojciech Lorenz entitled Powrót odstraszania w Europie od teorii do praktyki [Return of deterrence in Europe. From theory to practice] has been published in Sprawy Międzynarodowe (Lorenz, 2017). Its author is a leading researcher of international security issues at the Polish Institute of International Affairs (the official Ministry of Foreign Affairs think-tank) and his expertise is evident in a succinct and elegant summary of current thinking on Russia-NATO military relations (naturally from Polish and wider Allied perspective). Lorenz correctly identifies Russian elites' threat perceptions as a key to understanding the severity of the crisis currently affecting NATO-Russia relations. It is a very important point to stress (as Lorenz does) 
that Russian leaders perceive themselves more endangered than during the Cold War. This stems from their view that West is encroaching on their most immediate (and dear) sphere of influence and at the same time threatens the very foundations of their regime's continued rule over the Russian Federation. Such considerations lie at the roots of Moscow's increasing willingness to threaten the use of military force in order to achieve its objectives. In Lorenz's opinion these objectives amount to change of the post-Cold War status quo in Europe. Although deep Russian dissatisfaction with the post-1989 settlement is unquestionable, it is worth to mention the other view on the matter. Analysing the pattern of Moscow's behaviour both before and after the start of the Ukrainian war, it can be argued that it is not aiming to completely tear down the current international order. Russia's continuous calls for a kind of "new reset" in relations with the West, willingness for economic engagement with NATO states and constant participation in at least some of the global governance institutions can be seen as proofs that its spectacular sabre rattling is aimed more at renegotiation of its position in the current international order.

Important as these grand strategy questions are, it is beyond doubt that NATO is facing an acute operational (or military strategy) problem of how to effectively deter further Russia encroachment on Allied positions in Eastern Europe. Lorenz reaches for the classics of deterrence theory to offer his take on this puzzle. It starts with a historical comparison. In the Cold War years the Alliance had an effective deterrence strategy based on two pillars: considerable conventional forces which could offer strong resistance to Soviet attack (deterrence by denial) and massive nuclear arsenal (deterrence by punishment). In contrast, the current NATO deterrence posture (as crafted during the Wales and Warsaw Summits) is not nearly as effective. That's because conventional forces deployed on the Eastern Flank are clearly insufficient to offer anything more than token resistance to any serious Russian attack (a point made in a number of critical studies, see for example Smith, Hendrix 2016 or Shlapak, Johnson, 2016). To make this problem even worse for the Alliance, local Russian military dominance (evident for example in the development of the so-called Anti-Access/Area Denial capabilities in the Baltic and Black Seas; see Pothier, 2017) makes reinforcement of NATO forces in theatre at least problematic in the case of actual hostilities. For this reasons, the Alliance's current posture is simply too weak for an effective deterrence by denial. At the same time the threat of punishment (nuclear or otherwise) is not considered very credible (this can be seen for example in a heated debate generated by Matthew Kroenig's article advocating a rethink of NATO's nuclear strategy, see: Kroenig 2015, Pifer, Kulesa, et.al 2015) Lorenz correctly assumes that such a situation allows Russia to effectively apply three aggressor's strategies (short of full-scale attack): fait accompli, limited probe and controlled pressure. It can be argued that when it comes to NATO states Moscow limits itself (so far) with controlled pressure.

Perhaps the most interesting part of Lorenz's article concerns his ideas on proper way for NATO to develop an effective deterrence strategy vis-à-vis Russia. On the military level he advocates strengthening of capabilities for precision attacks on first echelon of advancing Russian forces. This argument clearly builds on the 1980s Air Land Battle and follow-on-forces attack concepts. It is also similar to US Army's doctrinal evolution in the form of Multi-Domain Battle (Shmuel, 2017). In Lorenz's opin- 
ion effective ability to hit advancing Russian forces with precision fires would provide both deterrence by denial (by slowing down or even stopping Russian attack) and punishment (through heavy personnel and materiel losses). But even more important (and often overlooked by analysts) is the political objective of this military strategy. Lorenz is clear that the ultimate purpose of the required military build-up is to create conditions in which Russia would not feel compelled to use force at all. This hints at an attempt at a grand bargain allowing NATO-Russia interests to be deconflicted and new stable order in Europe to be created. However, the author is clear that in order for the Alliance to achieve this goal it needs first to build a position of strength which will discourage Russia from seeking disproportionate concessions based on military superiority. This suggestion actually sounds like a page taken from the latest US National Security Strategy talking about "peace through strength." Attractive as this proposition is, it raises some serious questions laying at the heart of the current NATO debates about Russia strategy. First, on the operational-military level, development of capabilities to effectively engage Russian ground forces with precision fires will require significant technological innovation and financial investment to deal with a rich toolkit of Russian countermeasures (air and missile defences, electronic warfare, not to mention considerable Russian capabilities for counter-attack). This is not an unsurmountable challenge for the world's most advanced military alliance, but it will take time, money and political will which might be difficult to mobilise. The bigger question relates however to the political-strategic effects of the entire undertaking. It can be argued that effective deterrence will require not just an ability to hit forward echelons of advancing Russian forces, but also (or maybe even primarily) their rear elements with reserves and supporting command, communications and logistics infrastructure. Such militarily prudent approach would run counter to the overarching goal of building stable political relations with Russia. If we assume that current crisis is at least partially caused by record levels of Russian insecurity, then it is logical that increased NATO ability to reach and hit critical targets even deeper in Russian territory would only make Russian leaders more scared and less willing to compromise. The controversies surrounding US Ballistic Missile Defence initiatives in Europe serve as an example of how ambiguities created by weapons systems which (potentially) blur the lines between offensive and defensive capabilities (if such line can reasonably be drawn in the first place) can potentially destabilise the relationship.

The entire debate about the evolution of international security environment both globally and more importantly in Eastern Europe is of great interest to Poland and it is a natural responsibility of Polish strategic studies community to analyse and explain this phenomena. Lorenz's article aims for this presenting the problem from NATO level. Andrzej Dybczyński focuses his research specifically on the case of Poland. Dybczyński is a recognized scholar of alliance theory and his article: "Double-track Asymmetry: The Alliances of the Republic of Poland in the XXIst Century" in "The Polish Quarterly of International Affairs" is an application of alliance theory to the case of Polish alliance policy (Dynczyński, 2017). The author starts with a standard diagnosis, that from the Polish perspective a very favourable period in European history has come to an end. The resurgence of Russia, crisis of the EU and unpredictability of Trump administration's policies have jointly ended a sort of "honeymoon period" 
in which Polish alliance policy was conducted based on broad domestic support and without the risk of errors seriously endangering the state; future position. In this situation Dybczyński claims that: "Poland urgently needs to formulate a more sophisticated alliance policy than the existing one. This concerns not so much the choice of allies $[\ldots]$ as, first and foremost, the way it functions within existing alliances" (Dybczyński, 2017: 26). The author believes that change in Polish alliance policy is necessary for three main reasons: 1) alliances are crucial for safeguarding Polish national security because Poland is too weak to defend itself on its own; 2) the Trump administration seems to change the US alliance policy towards more transactional approach and 3) there are "four handicaps that burden Polish thinking about alliances in general and which reflect powerfully on the Polish elite's ability to conduct effective alliance policy in the country's objectively very difficult situation" (Dybczyński, 2017: 27). These handicaps are an especially interesting addition to the analysis, reflecting on some defining features of Polish strategic culture. According to Dybczyński they include: the absence of a tradition of alliance policies resulting from preference rather than necessity; very narrow real choice of alliances that could be effective; mythical romantic perception of alliances shared by a sizable part of the Polish public and, to some extent, by the elites as well and finally a deficit of reflection on alliances in the output of Polish "internatiology" (Dybczyński, 2017: 27-28).

The main strength of Dybczyński's article lies in the application of a developed alliance theory to produce recommendations for Polish alliance policy. They are conditioned by an asymmetric character of alliance relationships the country finds itself in and all the complexities of an alliance dilemma (composed of opposing risks of abandonment and entanglement) which they bring. While the effects of asymmetry in Poland's relationship with the USA is extensively researched, the freshness of Dybczyński's analysis stems from shedding light on Warsaw's also asymmetric alliance with the Baltic states (Lithuania, Latvia and Estonia). The author is clear in stating that both relationships must be managed with alliance theory's findings in mind. In practice Dybczyński focuses on the relationship with USA, which is understandable considering its fundamental importance for Polish security policy. He names four main factors determining an alliance member's ability to solve (or at least manage) the alliance dilemma: the degree of conflict with the enemy, availability of alternative solutions, number of interests shared with the stronger partner and weaker partner's own strength. Their analysis leads to some interesting conclusions. Some are quite conventional and prevalent in the current debate, like strengthening of Polish defence capabilities or exploration of new fields of Polish-American cooperation (for example in the sphere of energy trade). The most interesting conclusions relate to relations with Poland's biggest neighbours - Germany and Russia. Although Russia is the raison d'être and target of Polish alliance policy, Dybczyński clearly states that "[...] it is in Poland's interest to seek steadily improvement in its relations with Russia with a view to reduce its dependence on United States" (Dybczyński, 2017: 32). This corresponds with Lorenz's remark that NATO should in the end seek an accommodation with Moscow. Concerning Germany, Dybczyński is very clear that Poland should seek to strengthen bilateral relations with its western neighbour as another way to lessen its dependency on United States. This recommendation seems especially prudent in 
the context of growing calls for closer European cooperation on security issues meant partially as a hedge against perceived weakening of American commitment to the Old Continent. Another interesting remark by Dybczyński which goes against conventional wisdom prevailing among security analysts concerns the effects of Trump administration's perceived transaction based approach to alliances. That author actually believes that Poland may draw benefits from it (if played well). He specifically highlights Warsaw's relatively high level of defence expenditure (measured by GDP share) commensurate with alliance commitments (not upheld by many allies). In Dybczyński's opinion it can be presented to Washington as a proof of Poland keeping its side of the bargain. It seems that Polish government has adopted just that approach, announcing new potential defence deals with American companies on the eve of Trump's visit and continuing participation in anti-ISIS coalition.

Dybczyński ends his article with a set of recommendations for improvement of Polish alliance policy. They can be summarised as such: 1) closely analyse the US alliance behaviour 2) seek to equalise the level of threats in Poland's security environment (providing interesting suggestion that joining the Eurozone would make it difficult for EU states to abandon Warsaw in a time of crisis) 3) thwart Russia's attempts at uneven threat distribution among NATO states 4) strengthen security cooperation with Baltic states, Finland and Romania. All of these recommendations are self-evidently sensible and are (arguably) followed through by successive Polish governments. Summarising the relevance of Dybczyński's article it must be once again stressed that it is a very successful attempt to apply strategic studies theoretical achievements (in this case alliance theory) to a specific case study (Polish security policy) with very clear and far-sighted recommendations for decision makers. It also shows a rather constrained environment in which Polish security policy must be conducted. Dybczyski is right in calling for more sober and sophisticated alliance policy, however admits that in the current situation there is no attractive alternative to relationship with USA. He calls rather for modifications to a direction of alliance policy that is constant for the entire post-1989 period. This clearly demonstrates that in the current geopolitical setting Poland has a rather limited room for manoeuvre in its security policy. The summary of Warsaw's alliance options seems to boil down to a familiar abbreviation - TINA (There Is No Alternative).

Two previously reviewed articles adopt a realist perspective on Russia-West relations. It is interesting to explore different theoretical approaches to this issue. Here a good starting point is provided by Paulina Matera in her text Konstruowanie interesu narodowego - przypadek sankcji Stanów Zjednoczonych i Unii Europejskiej wobec Rosji [published in Stosunki Międzynarodowe (Matera, 2017). As suggested in the title she adopts constructivist perspective to explain the antagonism between Moscow and the West. Matera starts with a clear thesis: the sanctions adopted by United States and European Union are ineffective, because they are not causing any significant change in Moscow's behaviour. At the same time they generate significant costs for Western states. Thus, a question arises, why the sanctions regime is being maintained despite been counterproductive for its creators? To answer it the author is delving into images of the other created by both sides in this dispute. For Matera key to understating Russia-West relations lies in popular opinions on both sides which tend to perceive 
the opponent as sinister and hostile. The author points out that: "In the case of Russian actions against Ukraine, United States stresses its identity as a defender of freedom, democracy, with an obligation to react to infringement of the right to territorial integrity" (Matera, 2017: 102). At the same time: "The United States is perceived in Russia as an arrogant state, which desires to expand its influence and for that aim interferes in Russia's security sphere, weakening its [Russia's] position in the international arena" (Matera, 2017: 103). Naturally, these perceptions are long-held and derived from extensive historical experience. This mutual distrust clashes with extensive economic engagement between Moscow and the West. Matera points out that according to data compiled by the European Commission and the US Census Bureau in 2012 Russia was the third biggest trading partner for the EU (after US and China), while US-Russia trade was more limited (although with important investments of several big American corporations in that country). This leads to a conclusion that sanctions imposed after the annexation of Crimea generate significant economic pain for Western economies without bringing clear political benefits. Matera claims that sanctions are ineffective because they don't undermine Vladimir Putin's position as the country's leader. Russia didn't allow itself to be marginalised on the international arena and even made itself indispensable in determining future of Syria. In the author's opinion sanctions are maintained due to Western public opinion's negative attitudes towards Russia and leaders' resolve to punish the violation of important international norms of non-aggression and territorial integrity.

The entire argument presented in the article is compelling and brings into attention important aspects of current Russia-West relations. However, several of its points can be disputed. While it is true that sanctions didn't achieve their maximalist goals (like the reversal of Crimea's annexation) it is arguable whether their impact on Russia economy, Putin's position and (in consequence) Russia's international behaviour is nonconsequential. Russian economy has been hit hard by capital outflows and constraints on cooperation with Western companies in crucial sectors (Madej, 2015). Naturally, we cannot tell this with certainty but it can be claimed that Russian constraint in further escalation of the conflict with the West has been partially caused by the effects of sanctions. Matera consequently claims that sanctions are causing considerable pain on the Western side, but the strength of the argument would have been enhanced by more extensive data showing the scale of the costs incurred. The unquestionable strength of the article lies in application of constructivist perspective to highlight an important aspect of the Russia-West antagonism which are the mutual perceptions. Mistrust is undoubtedly an important factor contributing to deterioration of relations and rise of antagonism, as pointed out for example by Legvold (Legvold, 2016). However, the article lacks a more extensive analysis of attitudes and discourse on both sides to prove the point. Moreover, it is always risky to adopt single cause explanations for such complex processes as great power relations. As already pointed out by (among others) Lakomy and Sułek there are more structural factors at play than simple misperception. Nevertheless, Matera's article is an interesting addition complementing other studies on Russia-West antagonism.

The short and subjective review of Polish strategic studies writings presents attempts by Polish scholars to grapple with the issues raised by profound changes 
in global and regional international security environment. As already mentioned, the popularity of topics related to great power competition, deterrence and armed conflicts clearly reflects the global state of the discipline. If any broader conclusions can be drawn from all the articles mentioned in this texts they would point to the fact that strategic studies scholars tend to properly recognise the character of these changes. As always, it is way more difficult to predict their future effects. We are definitely living in times of strategic uncertainty. This point is nicely captured by Jacek Reginia-Zacharski in his article Strategie (nie)bezpieczeństwa we wspótczesnych , społeczeństwach ryzyka” [Strategies of (in)security in contemporary "risk societies"] from "Sprawy Międzynarodowe" (Reginia-Zacharski, 2017). When analysing current state of strategy making he invokes Ulrich Beck's concept of "risk society." His observation is that current threats and challenges are particularly complex and unpredictable. At the same time the social pressure on governments to actively counter them is very high which leads leaders to take actions which create and exacerbate risks of their own. It seems to be a fitting summary of our current predicament. As I have already remarked in previous editions of this review, the current period of international disorder creates a grim reality for us to live in, but at the same time it allows for a strong case for further development of strategic studies.

\section{REFERENCES}

Balcerowicz B. (2017), O przyszłych wojnach [On future wars], "Kwartalnik Bellona" ["Bellona Quarterly"], No. 1.

Concept of Defence of the Republic of Poland (2017), http://www.mon.gov.pl/d/pliki/rozne/2017/05/ KORP_DRUK_v03_mn2.pdf(17.02.2018).

Dybczyński A. (2017), Double-track Asymmetry: The Alliances of the Republic of Poland in the XXIst Century, "The Polish Quarterly of International Affairs", No. 1.

Ja Ian Chong, Hall T. H. (2014), The Lessons of 1914 for East Asia Today: Missing the Trees for the Forest, "International Security," Vol. 39, No. 1.

Kondrakiewicz D. (1999), Systemy równowagi sit w stosunkach międzynarodowych [Balance of power systems in international relations], Lublin.

Kroenig M. (2015), Facing Reality: Getting NATO Ready for a New Cold War, "Survival: Global Politics and Strategy," Vol. 57, No. 1.

Legvold R. (2016), Return to Cold War, Cambridge-Malden.

Lorenz W. (2017), Powrót odstraszania w Europie od teorii do praktyki [Return of deterrence in Europe. From theory to practice], "Sprawy Międzynarodowe" ["International Affairs"], No. 2.

Łakomy M. (2017), Intensyfikacja rywalizacji mocarstw jako zagrożenie militarne dla bezpieczeństwa międzynarodowego $w$ drugiej dekadzie XXI wieku [Intensification of great power rivalry as a military threat for international security in the second decade of the XXIst Century], "Sosunki Międzynarodowe” [„International Relations”], Vol. 53, No. 2.

Madej A. (2015), Sankcje i kontrsankcje. Przyczyny obecnego kryzysu ekonomicznego w Rosji [Sanctions and Counter-sanctions: Causes of the current economic crisis in Russia], "Bezpieczeństwo Narodowe" ["National Security"], No. 2. 
Matera P. (2017), Konstruowanie interesu narodowego - przypadek sankcji Stanów Zjednoczonych $i$ Unii Europejskiej wobec Rosji [Constructing the national interest - case of US and EU sanctions against Russia], "Stosunki Międzynarodwe" ["International Relations"], Vol. 53, No. 1.

Mazarr M. J. (2015), Mastering the gray zone: understanding a changing era of conflict, Carlisle.

National Security Strategy of the United States of America (2017), https://www.whitehouse.gov/wpcontent/uploads/2017/12/NSS-Final-12-18-2017-0905.pdf (17.02.2018).

Pifer S., Kulesa L. et al. (2015), Forum: NATO and Russia, "Survival: Global Politics and Strategy," Vol. 57, No. 2.

Pothier F. (2017), An Area-Access Strategy for NATO, "Survival Global Politics and Strategy," Vol. 59, No. 3.

Qiao Liang, Wang Xiangsui (1999), Unrestricted Warfare, Beijing, http://www.c4i.org/unrestricted. $\operatorname{pdf}(03.11 .2017)$.

Reginia-Zacharski J. (2017), Strategie (nie)bezpieczeństwa we współczesnych , społeczeństwach ryzyka" [Strategies of (in) security in contemporary "risk societies"], "Sprawy Międzynarodowe" ["International Affairs"], No. 2.

Ruszel M. (2017), Strategia polityki eneregetycznej republiki Federalnej Niemiec [The strategy of energy policy of the Federal Republic of Germany], "Sprawy Międzynarodowe" ["International Affairs"], No. 2.

Shlapak D. A., Johnson M. W. (2016), Reinforcing Deterrence on NATO's East-ern Flank Wargaming the Defense of the Baltics, RAND Corporation, https:/www.rand.org/content/dam/rand/ pubs/research_reports/RR1200/RR1253/RAND_RR1253.pdf (04.06.2017).

Shmuel S. (2017) Multi-Domain Battle: AirLand Battle, Once More, with Feeling, "War on The Rocks," 20.06.2017, https://warontherocks.com/2017/06/multi-domain-battle-airland-battleonce-more-with-feeling/ (17.02.2018).

Smith J., Hendrix J. (2016), Assured Resolve Testing Possible Challenges to Baltic Security, Center for A New American Security, https://www.cnas.org/publications/reports/assured-resolvetesting-possible-challenges-to-balticsecurity (04.06.2017).

Starrs S. (2013), American Economic Power Hasn't Declined-It Globalized! Summoning the Data and Taking Globalization Seriously, "International Studies Quarterly," Vol. 57, No. 4.

Sułek M. (2017), Transformacja globalnego uktadu sit po zimnej wojnie [Transformation of the global balance of power after the Cold War], "Rocznik Strategiczny 2016/17" [Strategic Yearbook 2016/17'].

Wiśniewski R. (2018 upcoming), EU-NATO cooperation in countering hybrid threats: comparing capabilities and defining roles, in: Security Beyond the State: The EU and the others (eds.) D. Irrera, C. Morsut, Opladen-Berlin-Toronto.

Wiśniewski R., Hensarling B. (2015), Power in 2025: A Global Ranking, "R/evolutions: Global Trends \& Regional Issues," Vol. 3, No. 1, http://revjournal.org/wp content/uploads/ rev3/05rev3_wisniewski_hensarling.pdf (17.02.2018).

\begin{abstract}
The text is a review of selected articles from leading Polish academic journals dealing with the topic of international security. It aims to present the most important topics of current debate taking place in Polish strategic studies.
\end{abstract}

Keywords: strategic analyses, Polish journals 


\section{POLSKIE ANALIZY STRATEGICZNE - PRZEGLĄD PUBLIKACJI 2017 ROKU}

\section{STRESZCZENIE}

Niniejszy tekst stanowi przegląd wybranych artykułów z czołowych polskich czasopism naukowych podejmujących tematykę bezpieczeństwa międzynarodowego. Ma on ukazać najważniejsze wątki w aktualnej debacie toczącej się w ramach polskich studiów strategicznych.

Słowa kluczowe: analizy strategiczne, polskie czasopisma 